Kinestetik : Jurnal Ilmiah Pendidikan Jasmani 5 (3) (2021)

Kinestetik : Jurnal Ilmiah Pendidikan Jasmani

https://ejournal.unib.ac.id/index.php/kinestetik/index

DOI : 10.33369/jk.v5i3.17396

\title{
ANALYSIS OF THE RELATIONSHIP BETWEEN \\ CONCENTRATION AND BALANCE AGAINST YOEP CHAGI KICK POOMSAE MOVEMENT TECHNIQUE SPORTS CLUB TAEKWONDO ACHIEVEMENT STATE UNIVERSITY OF JAKARTA
}

\author{
Fahmy Fachrezzy ${ }^{1 *}$, Uzizatun Maslikah², Masnur Ali³ ${ }^{3}$ Iwan Hermawan ${ }^{4}$, \\ Reggie Reginald ${ }^{5}$, Haris Nugroho ${ }^{6}$ \\ ${ }^{12345}$ State University of Jakarta: Physical Education, Faculty of Sport Science, Universitas \\ Negeri Jakarta, Jakarta, Indonesia \\ ${ }^{6}$ Sebelas Maret University: Sports Training Education, Faculty of Sports, Universitas Sebelas \\ Maret, Surakarta, Indonesia
}

\section{Article Info}

Article History :

Received : August 2021

Revised : September 2021

Accepted : September 2021

Available online : September 2021

Keywords:

Concentration, balance, yeop chagi, taekwondo

\section{Abstract}

The purpose of this study was to analyze the relationship of Concentration and Balance with yeop chagi kicks Achievement Sports Club taekwondo State University of Jakarta. The population and sample in the study were college students who attended a sports club achievement of 35 men with exercise characteristics for a year or more. Data collection techniques use tests and measurements of concentration, balance, and yeop chagi kicks. Technical data analysis uses a significant multiple-level correlation $\alpha 0.05$ overall data analysis using SPSS software version 20. The results of this study can conclude that: (i) there is a relationship between concentration and yeop chagi kick poomsae movement technique; (ii) there is a relationship between concentration and yeop chagi kick Poomsae movement technique; and (iii) there is a relationship between Concentration and Balance with yeop chagi kick poomsae movement technique. But in this study only involved one factor of physical condition and psychology, for further research will involve other physical condition factors namely speed, flexibility, endurance, and related in this study by the characteristics of taekwondo achievement, especially in poomsae numbers at the State University of Jakarta.
Corresponding address : Jl. Tanjung Gedong No. 9A Rt. 003

Rw.016 Kel. Tomang Kec. Grogol petamburan, Jakarta Barat

*Corresponding email : fahmyfachrezzy@unj.ac.id
ISSN 2685-6514 (Online)

ISSN 2477-331X (Print) 


\section{INTRODUCTION}

Taekwondo is now increasingly advanced and popular, three materials can be learned in taekwondo, namely moves in taekwondo martial arts (Poomsae), fighting in taekwondo martial arts (kyorugi), and the technique of breaking hard objects with kicks and punches (kyukpa) (Asi et al., 2021; Bae \& Roh, 2021; Fachrezzy et al., 2021; Monks et al., 2017; Singh, 2020; Sukmawati, 2020; Tayshete et al., 2020a). For now, taekwondo championships are most often held in various regions, both district, provincial, and national level championships are kyorugi (fight) category, and also Poomsae (moves) but at this time in some taekwondo championship events have started holding kyukpa (breakdown) category matches (Lee \& Jung, 2020; Seo et al., 2020).

Taekwondo (Poomsae) is a type of martial arts that combines various types of oriental martial arts. Taekwondo (Poomsae) involves hands and feet, but they prefer legs. As the legs are a large group of muscles, that can give a more powerful impact (Koshcheyev, 2020).

Poomsae entered Indonesia and began to be competed in the national championship in 2009 in Magelang, while for the Sea Games, Poomsae was first contested in Laos in 2009. In 2012, Poomsae was first contested at National XII Sports Week in Riau, and at the time of the Asian World Taekwondo Federation Poomsae championship was first held in Kazakhstan in 2012. Furthermore, in 2018 for the first time, the Poomsae category was contested in the prestigious Asian games where Indonesia had the opportunity to host the biggest sporting event in Asia.

Poomsae is a combination movement designed to train without an instructor, using a fixed performance base of attacking and defending (AhReum
\&So, 2019; Choi \& Joo, 2016; Chung \& Johnson, 2019; Fachrezzy et al., 2021; Hyuk, 2013; Kim et al., 2020; Kurniawan \& Gusrianty, 2019; Lin, 2020; Priyadi, 2017; Shin et al., 2016; Yalfani \& Taghizadeh, 2019).

To perform yeop chagi kick movements at taekwondo achievement sports clubs on Poomsae numbers requires balance and qualified concentration. Balance is the ability to maintain a center of gravity at the fulcrum especially when upright (Aytar et al., 2012; Irfan et al., 2019; Leong et al., 2011; Pedlar et al., 2018; Polat, 2018; Tayshete et al., 2020b). Concentration is the concentration of attention or thought on a thing (Hidayati, 2015; Hutabarat et al., 2017; Kholilah \& Solichatun, 2018; Nusufi, 2016; Widodo \& Hafidz, 2018). Thus concentration and balance are some of the dominant factors in doing yeop chagi kicks in taekwondo achievement sports clubs on Poomsae numbers.

To train concentration and balance requires qualified physical exercise through programmatic and structured exercises. Physical activity is a person's ability to do the next activity without experiencing significant fatigue (Fachrezzy et al., 2020; Hermawan et al., 2021; Jariono et al., 2001; Jariono, Fachrezzy, et al., 2020; Jariono, Nursubekti, et al., 2020) (Nugroho et al., 2021).(Nugroho et al., 2021)

In Indonesia, Poomsae developed quite well and Poomsae athletes began to appear in every region. These athletes have an interest in poomsae because in this poomsae category one Poomsae athlete can play in two categories at once, and at this time the poomsae category is more challenging than the kyorugi (fight) category, with the new rules requiring athletes to compete freestyle poomsae during the semi-finals allows these poomsae athletes to increase their creativity to make movements that are 
quite complicated and combined with musical accompaniment.

At The State University of Jakarta poomsae experienced quite good development. In 2014 for the first time, State University of Jakarta participated in a match at the Provincial Student Sports Week. In 2015 poomsae Universitas Negeri Jakarta already has a strong team in each of its poomsae numbers to compete in the national student championship held at Sebelas Maret University, Solo, Central Java. In 2016 poomsae State University of Jakarta brought two teams to compete in the national student championship located in Lombok, NTB. Until now poomsae State University of Jakarta is increasingly advanced and poomsae athletes who are at The State University of Jakarta have become many athletes to defend their respective home regions.

Based on the phenomenon of stringy facts, researchers researched the relationship between concentration and balance with yeop chagi kicks at taekwondo achievement sports clubs on Poomsae numbers at State University of Jakarta. The goal of the study was to describe and analyze the relationship between concentration and balance with yeop chagi kicks in taekwondo achievement sports clubs on poomsae numbers.

\section{METHODS}

Descriptive methods with quantitative approaches used in this study used a correlational design which is an approach to find the answer to the problem through the formulation of the problem that has been formulated, namely the relationship of self-confidence and balance with the Yeop Chagi kick poomsae movement technique in students of Universitas Negeri Jakarta who follow the taekwondo restation sports club, the constellation of research can be seen in the following figure:

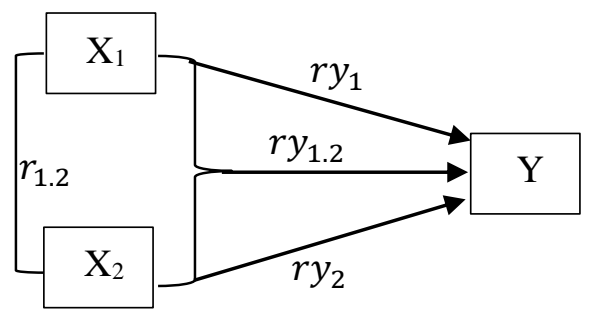

Figure 1. constellation of research

Based on the picture above can be anointed, namely concentration $\left(\mathrm{X}_{1}\right)$, balance $\left(\mathrm{X}_{2}\right)$, and kick Yeop Chagi movement technique poomsae students taekwondo achievement club at the State University of Jakarta (Y).

\section{Participants}

The sample in this study was a student son of 35 people who participated in taekwondo achievement sports club on poomsae number of State University of Jakarta.

\section{Sampling Procedures}

The sampling procedure in this study used purposive sampling, considering the characteristics of the sample following a minimum training period of one year or more joining a taekwondo achievement sports club on poomsae numbers at The State University of Jakarta.

\section{Materials and Apparatus}

Data collection techniques use tests and measurements: (i) concentration is that the student stands on one leg by closing his eyes with time by the student's ability as long as he is able, (ii) the balance test by standing upright with one dominant foot the other foot is affixed to the knee of the fulcrum foot. Calculated the length of time maintaining standing within seconds. The score was obtained with the longest time record standing one foot on tiptoe, 
and eyes opened, each candidate was given the opportunity 3 times and taken the best time; and (iii) test kick Yeop Chagi poomsae movement technique, students perform kicks for one minute as much as possible.

\section{Procedures}

This study uses the following procedures: (1) the first stage of the researcher performs tests and measurements consisting of tests of concentration, balance, and kick Yeop Chagi poomsae movement technique; and (2) researchers category data after that equated one by using the formula T-Skor with the formula T_score $=50 \pm$ $10\left(\frac{X-\bar{x}}{S D}\right)$ for to equalize the unit of each study variable, where the constant $50 \pm 10$ value, $X$ is the raw data score, $\bar{X}$ is the average value and SD is the standard deviation.

\section{Design or Data Analysis}

Data analysis in this study uses descriptive and inferential analysis. Descriptive analysis in this study looked for average values and standard deviations while for inferential analysis to test the normality of data, and double correlation analysis using product-moment correlation tests. Overall data analysis using SPSS software version 20.0

\section{RESULTS}

\section{Descriptive analysis}

The results of the descriptive analysis of research data on concentration $\left(\mathrm{X}_{1}\right)$, balance $\left(\mathrm{X}_{2}\right)$, and yeop chagi kicks, poomsae movement techniques, students of the State University of Jakarta taekwondo sports club (Y) can be seen in table 1 .
Table1. Results of descriptive analysis of concentration, balance, and kick yeop chagi poomsae movement technique

\begin{tabular}{llll}
\hline Statistics & \multicolumn{3}{l}{ Research variables } \\
\cline { 2 - 4 } & $\mathbf{X}_{\mathbf{1}}$ & $\mathbf{X}_{\mathbf{2}}$ & $\mathbf{Y}$ \\
\hline Average value & 32.89 & 34.63 & 36.63 \\
\hline $\begin{array}{l}\text { Standard } \\
\text { deviation }\end{array}$ & 7.898 & 8.461 & 8.572 \\
\hline
\end{tabular}

Based on the results of the descriptive analysis in table 1 about the relationship of concentration and balance with yeop kick chagi poomsae movement technique. This descriptive analysis of research data from 35 samples obtained an average value of 32.89(X1) respectively, a balance (X2)of 34.63, and a yeop kick of poomsae movement technique (Y) of 36.63. Furthermore, for the standard deviation of each for concentration $\left(\mathrm{X}_{1)}\right.$ of7,898, balance (X2) of 8,461, and yeop kick chagi poomsae movement technique (Y) of 8,572. Thus it can be concluded that each treatment has an average difference in value in taekwondo achievement sports clubs on poomsae numbers at The State University of Jakarta.

\section{Prerequisite test}

The normality test is used as a prerequisite for a hypothesis test. This normality test using the KolmogorovSmirnov Z (KS-Z) test can be seen in the following table:

Table 2. Results of data normality analysis

\begin{tabular}{lccc}
\hline \multirow{2}{*}{ Statistics } & \multicolumn{3}{c}{ Research variables } \\
\cline { 2 - 4 } & $\mathrm{X}_{1}$ & $\mathrm{X}_{2}$ & $\mathrm{Y}$ \\
\hline $\begin{array}{l}\text { Kolmogorov- } \\
\text { Smirnov Z }\end{array}$ & 1.226 & 1.083 & .755 \\
\hline $\begin{array}{l}\text { Asymp. Sig. (2- } \\
\text { tailed) }\end{array}$ & .099 & .192 & .620 \\
\hline
\end{tabular}


Based on Table 2 above is a recapitulation of the results of testing the normality of research variable data it can be concluded that the results of KolmogorovSmirnov Z (KS-Z) analysis in the entire data group turned out to be greater than the value of $\alpha=0.05$ (KS-Z> $\alpha=0.05$ ). Thus it can be concluded that this study sample comes from a normally distributed population. After the normality test, the hypothesis is then done.

\section{Hypothesis Test}

Table 3. Hypothesis test results

\begin{tabular}{lcccc}
\hline Relationship & $\mathrm{r}_{\text {-count }}$ & $\begin{array}{r}\mathrm{r}_{\text {-table }} \\
(0,05)\end{array}$ & Sig. \\
\cline { 1 - 2 } $\mathrm{X}_{1}$ with Y & 0.986 & & \\
\cline { 1 - 2 } $\mathrm{X}_{1}$ with Y & 0.921 & 0.330 & 0.000 \\
\cline { 1 - 2 } $\mathrm{X}_{1.2}$ with Y & 0.986 & & \\
\hline
\end{tabular}

Based on the results of analysis a double correlation about concentration and balance with the kick Yeop Chagi Poomsae movement technique in table 1 above obtained a value of $r_{\text {_count }}$ of 0.986 , 0.921 , and 0.986 respectively while for $\mathrm{r}_{\text {_table }}(34(10) ; 0.05)$ of 0.339 with a significant level of $0.000<$ from $\alpha 0.05$. Based on these results, it can be concluded that there is a strong relationship or $\mathrm{H}_{0}$ rejected and accepted $_{\mathrm{H} 1}$. Thus it can be explained that there is a relationship between concentration and balance with Yeop Chagi kicks at taekwondo achievement sports clubs on poomsae numbers at The State University of Jakarta. This means that the coefficient can be generalized or can apply to the overall population of taekwondo athletes of The State University of Jakarta where a sample of 35 people was taken.

\section{DISCUSSION}

The results of this study have a strong relationship between concentration and balance with Yeop Chagi kicks in taekwondo achievement sports clubs on poomsae numbers at The State University of Jakarta. To find out the categorization of correlational interpretations referring to opinions (Sugiyono, 2017) can be seen in the following correlational interpretation table:

Table. 4 Guidelines for providing an interpretation of correlation coefficients

\begin{tabular}{cc}
\hline $\begin{array}{c}\text { Coefficient } \\
\text { interval }\end{array}$ & Relationship level \\
\hline $0,00-0,199$ & Very low \\
\hline $0,20-0,399$ & Low \\
\hline $0,40-0,599$ & Keep \\
\hline $0,60-0,799$ & Strong \\
\hline $0,80-1,000$ & Very strong \\
\hline
\end{tabular}

Koefisin correlation obtained the relationship between concentration and balance with Yeop Chagi kick in taekwondo achievement sports club on poomsae number at State University of Jakarta of 0.986 included in the interpretation of correlation coefficient in the very strong category. This value is at a coefficient interval between 0.80-1,000. This shows a very strong relationship of concentration and balance with Yeop Chagi kicks at taekwondo achievement sports clubs on poomsae numbers at The State University of Jakarta. While the significant degree of coefficiency of onesided (1-tailed) correlation of output measured from probability results in a significance value of 0.000 . Because the probability is below 0.05 , the level of aconcentration and balance have a positive direct relationship with Yeop Chagi kick at taekwondo achievement sports clubs in poomsae numbers at State University of Jakarta.

This study takes obese children as the research objects to explore the influence of Taekwondo Poomsae training on obese children. From the above results, regular Taekwondo Poomsae training can reduce the weight, body mass index and body fat rate of obese children. In the future research, in order to make obese children 
have fun and active sports, it is necessary to popularize a variety of sports, and increase school sports time. When students insist on physical activities, it is not only to prevent obesity, but also to live a healthy and lively school life(Lin, 2020).

Concentration is a person's ability to focus on one particular task so that other stimuli both from the outside and inside will not interfere. An athlete who has good concentration will produce good kicking skills as well.

Concentration on athletes is needed during the games because if an athlete loses his concentration it will be fatal both defeat and injury (Irfan et al., 2019). Concentration is a factor that must be considered and improved because it has a positive relationship with skills in sports including when doing concentration kicks also has a role in kick speed.

Balance is one of the important factors in supporting daily activities and exercise (Leong et al., 2011; Pedlar et al., 2018; Polat, 2018). Based on the results of the analysis of research data showed that balance has a direct influence on Yeop Chagi kick skills. An athlete who has a good balance will produce good kicking skills as well.

At the time of kicking, the position of the body rests on only one leg, therefore good balance is required for athletes to be able to display good kicking techniques as resulted from previous research which states that balance is necessary because it has a significant relationship to the technical skills of an athlete both in the sport of games and in martial arts (Aligene \& Lin, 2013; Rogers et al., 2013).

Based on the results of this study, it can be argued that the ability of Yeop Chagi kick is determined by several factors, one of which is the balance which is a physical component, and psychological factors, one of which is concentration so it needs to be developed optimally to achieve optimal appearance.
In addition to the physical component, the mental aspect of concentration has a role in the ability of Yeop Chagi kicks. So to improve technical skills not only aspects of physical components that must be improved but also mental aspects need to be considered and trained.

\section{CONCLUSION}

The results of this study can be concluded: (i) there is a partially strong relationship between concentration and Yeop Chagi kick of 0.986; (ii) there is a partially strong relationship between balance with Yeop Chagi kick of 0.921 ; and (iii) there is a strong simultaneous relationship between concentration and balance with Yeop Chagi kicks in taekwondo achievement sports clubs on poomsae numbers at State University of Jakarta of 0.986 based on findings in this study, to improve the ability of Yeop Chagi kicks in taekwondo achievement sports clubs on poomsae numbers must pay attention to physical condition and psychological factors, one of which is concentration and balance. But this study only relaxes one of the factors of psychology and physical condition, for further research will involve the overall factor of a dominant physical condition associated with increasing Yeop Chagi kicks in taekwondo achievement sports clubs in poomsae numbers, as a foundation for achieving achievements at championships both nationally and internationally

\section{ACKNOWLEDGEMENT}

Thank you to the Faculty of Sports Sciences, State University of Jakarta who has fully facilitated to researchers to research young lecturer research grants in the fiscal year 2021. Furthermore, the researchers thanked the team and the 
team, coaches, and students of the taekwondo achievement sports club of State University of Jakarta to help the research process until the end of the study.

\section{REFERENCES}

AhReum, H., \& So, J. (2019). Kinematic and Kinetic Analysis of Taekwondo Poomsae Side Kick according to Various Heights of the Target. Korean Journal of Sport Biomechanics, 29(3), 129-135.

Aligene, K., \& Lin, E. (2013). Vestibular and balance treatment of the concussed athlete. NeuroRehabilitation. https://doi.org/10.3233/NRE-130876

Asi, A. M., Yilmaz, A. K., Karaduman, E., Mayda, M. H., Era, S., \& Kabadayi, M. (2021). Correlation of bilateral and ipsilateral strength ratios with balance in female taekwondo athletes. 16(December), 67-79. https://doi.org/10.18002/rama.v16i2.648 6

Aytar, A., Pekyavas, N. O., Ergun, N., \& Karatas, M. (2012). Is there a relationship between core stability, balance and strength in amputee soccer players? A pilot study. Prosthetics and Orthotics International.

https://doi.org/10.1177/03093646124458 36

Bae, J. Y., \& Roh, H. T. (2021). Regular taekwondo training affects mood state and sociality but not cognitive function among international students in South Korea. Healthcare (Switzerland), 9(7). https://doi.org/10.3390/healthcare90708 20

Choi, C. H., \& Joo, H. J. (2016). Motion recognition technology based remote Taekwondo Poomsae evaluation system. Multimedia Tools and Applications. https://doi.org/10.1007/s11042-0152901-1

Chung, B. K., \& Johnson, J. A. (2019). Taekwondo poomsae competitor perceptions of the official and new competition poomsae, field of play, and competition rules. Physical Activity Review. https://doi.org/10.16926/PAR.2019.07.0
4

Fachrezzy, F., Jariono, G., Maslikah, U., \& Nugroho, H. (2020). Functional Exercise Model for Weight Loss in Sports Science Faculty Students. International Summit on Science Technology and Humanity (ISETH) 2020, 159-165.

Fachrezzy, F., Maslikah, U., Safadilla, E., Reginald, R., \& Hendarto, S. (2021). Physical Fitness Of The Poomsae Taekwondo Athletes In Terms Of Agility, Balance And Endurance. Kinestetik: Jurnal Ilmiah Pendidikan Jasmani, 5(1), 111-119. https://doi.org/10.33369/jk.v5i1.14364

Hermawan, I., Indrawira, H., Maslikah, U., Jariono, G., \& Nugroho, H. (2021). Pelatihan dan Penyusunan Latihan Fisik Pada Anggota Komando Strategis Angkatan Darat ( KOSTRAD ). JURNAL ALTIFANI : Penelitian Dan Pengabdian Kepada Masyarakat, 1(1), 27-34. https://doi.org/10.25008/altifani.v1i1.11 5

Hidayati, R. (2015). Peran Konselor Sekolah Dalam Meningkatkan Konsentrasi Pada Siswa Hiperaktif (ADHD). Refleksi Edukatika. https://doi.org/10.24176/re.v5i1.431

Hutabarat, A. L., Watimena, F. Y., \& Fitranto, N. (2017). Hubungan Konsentrasi Dan Persepsi Kinestetik Terhadap Kemampuan Shooting Pada Pemain U-11 Tahun Ragunan Soccer School. Jurnal Ilmiah Sport Coaching and Education, $1(2)$, 78-92. https://doi.org/10.21009/jsce.01207

Hyuk, I. Il. (2013). Aesthetic values of taekwondo poomsae game. Philosophy of Movement: Journal of the Korean Society for the Philosophy of Sport, Dance \& Martial Arts.

Irfan, P., Harsono, A., \& Fahreyi, F. (2019). The Relationship of Balance and Concentration on Yeop Chagi' s Kick on the Taekwondo Deaf Poomsae Athletes of Santi Rama Slb-B School. 4(9).

Jariono, G., Fachrezzy, F., \& Nugroho, H. (2020). Application of Jigsaw Type Cooperative Learning Model to Improving the Physical Exercise Students Volleyball at Junior High School 1 Sajoanging. Journal of Reseacrh in 
Business, Economics, and Education, 2(5), 1019-1026. http://e-journal.stiekusumanegara.ac.id

Jariono, G., Nugroho, H., \& Hermawan, I. (2001). The Effect of Circuit Learning on Improving The Physical Fitness of Elementary School Students. International Journal of Educational Research \& Social Sciences, 2(2), 59-68. https://doi.org/https://doi.org/10.51601/ij ersc.v2i1.22

Jariono, G., Nursubekti, N., Indarto, P., Hendarto, S., Nugroho, H., \& Fachrezy, F. (2020). Analisis kondisi fisik menggunakan software Kinovea pada atlet taekwondo Dojang Mahameru Surakarta. Transformasi: Jurnal Pengabdian Masyarakat. https://doi.org/10.20414/transformasi.v1 $6 \mathrm{i} 2.2635$

Kholilah, E., \& Solichatun, Y. (2018). Terapi Bermain Dengan CBPT (Cognitive Behavior Play Therapy) Dalam Meningkatkan Konsentrasi Pada Anak ADHD. Psikoislamika : Jurnal Psikologi Dan Psikologi Islam. https://doi.org/10.18860/psi.v15i1.6662

Kim, J., Cheon, W., \& Park, J. (2020). Exploring the Motives of College TAEKWONDO Poomsae Athletes for Participating in the Poomsae Competitions. J-Institute, 5(1), 1-13. https://doi.org/10.22471/martialarts.2020 .5 .1 .01

Koshcheyev, A. (2020). Technical Training In The Non-Olympic Taekwondo (Poomsae) Direction During The Initial Preparation Phase. 157-164.

Kurniawan, W. J., \& Gusrianty, G. (2019). Sistem Pendukung Keputusan Seleksi Atlet Poomsae Taekwondo Dengan Metode Analityc Hierachy Process. JOISIE (Journal Of Information Systems And Informatics Engineering). https://doi.org/10.35145/joisie.v2i1.244

Lee, J., \& Jung, H. (2020). Tuhad: Taekwondo unit technique human action dataset with key frame-based cnn action recognition. Sensors (Switzerland), 20(17), 1-20. https://doi.org/10.3390/s20174871

Leong, H. T., Fu, S. N., Ng, G. Y. F., \& Tsang, W. W. N. (2011). Low-level Taekwondo practitioners have better somatosensory organisation in standing balance than sedentary people. European Journal of Applied Physiology. https://doi.org/10.1007/s00421-0101798-7

Lin, Q. (2020). Effect of Taekwondo Poomsae Training on Weight Loss of Obese Children. ATLATIS PRESS: Advances in Social Science, Education and Humanities Research, 457(Icsspeh), 121124.

https://doi.org/10.2991/assehr.k.200804. 116

Monks, L., Seo, M. W., Kim, H. B., Jung, H. C., \& Song, J. K. (2017). High-intensity interval training and athletic performance in Taekwondo athletes. Journal of Sports Medicine and Physical Fitness. https://doi.org/10.23736/S00224707.17.06853-0

Nugroho, H., Gontara, S. Y., Angga, P. D., Jariono, G., \& Maghribi, I. L. (2021). Quality Of Physical Condition Of Youth Pencak Silat Athletes Reviewed From Speed, Power. Kinestetik : Jurnal Ilmiah Pendidikan Jasmani, 5(1), 154-162. https://ejournal.unib.ac.id/index.php/kine stetik/article/view/14376

Nusufi, M. (2016). Melatih Konsentrasi Dalam Olahraga. Ilmu Keolahragaan.

Pedlar, C. R., Brugnara, C., Bruinvels, G., \& Burden, R. (2018). Iron balance and iron supplementation for the female athlete: A practical approach. In European Journal of Sport Science. https://doi.org/10.1080/17461391.2017.1 416178

Polat, S. Ç. (2018). The Effect of Technical Competence in Balance Elements of Rhythmic Gymnastics on the Sportive Success of Taekwondo Poomsae Athletes. Journal of Education and Training Studies. https://doi.org/10.11114/jets.v6i9.3375

Priyadi, A. (2017). Pengaruh Latihan Mental Imagery Terhadap Kemampuan Poomsae Pada Atlet Poomsae Cabang Olahraga Beladiri Taekwondo. Wahana Didaktika.

Rogers, M. E., Page, P., \& Takeshima, N. (2013). Balance training for the older athlete. International Journal of Sports Physical Therapy.

Seo, B.-D., Kim, H.-J., \& Ju, J.-Y. (2020). 
Effect of Muscle Fatigue on the Players. 2019(Dec 5).

Proprioception by the Taekwondo

Training Type. Journal of The Korean

Society of Physical Medicine, 15(3), 1-9. https://doi.org/10.13066/kspm.2020.15.3 .1

Shin, Y. S., Yang, S. M., Kim, M. Y., Lee, L. K., Park, B. S., Lee, W. D., Noh, J. W., Kim, J. H., Lee, J. U., Kwak, T. Y., Lee, T. H., Park, J., \& Kim, J. (2016). Differences in respirogram phase between taekwondo poomsae athletes and nonathletes. Journal of Physical Therapy Science. https://doi.org/10.1589/jpts.28.2495

Singh, S. (2020). Relationship Of Body Mass Indexwith Theperformance Of National Level Taekwondo Players. 07(07), 39653969.

Sugiyono. (2017). MetodePenelitian Kuantitatif, Kualitatif dan R\&D. Bandung: PT Alfabet. In Sugiyono. (2017). MetodePenelitian Kuantitatif, Kualitatif dan R\&D. Bandung: PT Alfabet.

Sukmawati, N. (2020). Biomotor Profile of Taekwondo Athletes Poomsae Putera Age Under 14 years in East OKU Regency 2019. Jipes - Journal of Indonesian Physical Education and Sport, 5(1), 34-42. https://doi.org/10.21009/jipes.051.05

Tayshete, I., Akre, M., Ladgaonkar, S., \& Kumar, A. (2020a). Comparison of Effect of Proprioceptive Training and Core Muscle Strengthening on the Balance Ability of Adolescent Taekwondo Athletes. 10(June).

Tayshete, I., Akre, M., Ladgaonkar, S., \& Kumar, A. (2020b). Comparison of Effect of Proprioceptive Training and Core Muscle Strengthening on the Balance Ability of Adolescent Taekwondo Athletes. International Journal of Health Sciences and Research, 10(6), 268-279.

Widodo, W., \& Hafidz, A. (2018). Kontribusi Panjang Lengan, Koordinasi Mata Tangan, dan Konsentrasi Terhadap Ketepatan Shooting Pada Olahraga Petanque. Prestasi Olahraga.

Yalfani, A., \& Taghizadeh, M. (2019). Prevalence and Mechanism of Sports Injuries in Poomsae Premier League 